\title{
Performance Evaluation of B. Braun Omnitest 5 Blood Glucose Monitoring System for Self-Monitoring of Blood Glucose
}

Kyungso Jeon ${ }^{1}$ and Miseon Shin $^{2}$

${ }^{1}$ Department of Laboratory Medicine and ${ }^{2}$ Division of Endocrinology and Metabolism, Hanil General Hospital, Seoul, Korea

Corresponding author: Kyungso Jeon Department of Laboratory Medicine, Hanil General Hospital, 308 Uicheon-ro, Dobong-gu, Seoul 01450, Korea Tel: +82-2-901-3720

Fax: +82-2-901-3606

E-mail: jks3393@hanmail.net
Background: We evaluated the accuracy of the B. Braun Omnitest 5 blood glucose monitoring system (BGMS; Infopia Co. Ltd., Korea), which was recently developed for selfmonitoring of blood glucose.

Methods: Precision was assessed according to Clinical and Laboratory Standards Institute guideline EP5-A3 with control materials containing low, normal, and high levels of glucose. Linearity was evaluated over the range of $52.5-548.0 \mathrm{mg} / \mathrm{dL}$ prepared from patient samples. For system accuracy, 100 capillary blood samples measured by the B. Braun Omnitest 5 BGMS were compared to plasma-equivalent blood glucose values of the fingertip blood samples measured by the YSI 2300 STAT PLUS glucose analyser (YSI Life Sciences, USA). Accuracy was evaluated according to the International Organization for Standardization (ISO) 15197: 2013 criteria.

Results: The range for the total coefficient of variation (\%) was $1.5 \%-4.9 \%$ for three lots of strips. Both within-run precision and within-laboratory precision fulfilled the manufacturer's claim. ISO 15197: 2013 states that more than 95\% of blood glucose measurement values must be within $\pm 15 \mathrm{mg} / \mathrm{dL}$ for ranges below $100 \mathrm{mg} / \mathrm{dL}$ and $\pm 15 \%$ for ranges above $100 \mathrm{mg} /$ dL. Each of B. Braun Omnitest 5 lots satisfied ISO 15197: 2013, as 98.5\% (197/200), 97.0\% $(194 / 200)$, and $99.5 \%(199 / 200)$ of values were within range. In consensus error grid analysis, respectively, $99.5 \%, 99.0 \%$, and $100.0 \%$ of measurement values of each lot were within zone A, indicating that an average of over $99.0 \%$ of values were within zone A.

Conclusions: B. Braun Omnitest 5 provided reliable results and satisfied the ISO 15197: 2013 accuracy criteria. This test is an appropriate BGMS for the self-monitoring of blood glucose. (J Lab Med Qual Assur 2016;38:234-242)

Key Words: Blood glucose monitoring system, Self-monitoring of blood glucose, Accuracy, Evaluation

Received April 12, 2016, Revision received August 22, 2016, Accepted September 9, 2016

\section{INTRODUCTION}

Diabetes is a major worldwide health epidemic that affected nearly 415 million people in 2015. Poorly managed diabetes leads to serious complications and early death in most countries, but with good self-management and health professional support, people with diabetes can live long, healthy lives [1]. Complications related to both type 1 and type 2 diabetes can be reduced by better regulation of blood glucose [2]. Self-monitoring of blood glucose (SMBG) enables diabetes patients to effectively control their blood glucose levels. Moreover, management of diabetes through diet, exercise, and chemical treatment can delay degeneration of the disease or arrival of complications. The blood glucose test thus is considered one of the most important point-of-care tests $[3,4]$. 
The analytical performance of blood glucose monitoring systems (BGMSs) is critical because their accuracy can affect decisions regarding glycaemic control, such as insulin dosage [5].

The International Organization for Standardization (ISO) 15197: 2013 standard recommends that two minimum criteria be fulfilled for a system to be considered accurate [6]. One criterion specifies that the overall difference in $95.0 \%$ of values should be within $\pm 15 \mathrm{mg} / \mathrm{dL}$ for concentrations $<100 \mathrm{mg} / \mathrm{dL}$ and $\pm 15 \%$ for those $\geq 100$ $\mathrm{mg} / \mathrm{dL}$; the other is that $99.0 \%$ of measured values fall within zones $\mathrm{A}$ and $\mathrm{B}$ of the consensus error grid (CEG) for type 1 diabetes.

The B. Braun Omnitest 5 BGMS (Infopia Co. Ltd., Anyang, Korea) was recently developed for SMBG. It is composed of B. Braun Omnitest 5 Blood Glucose Test Strips and a B. Braun Omnitest 5 Blood Glucose Test Meter, and adopts the GDH-FAD (flavin adenine dinucleotide-dependent glucose dehydrogenase) method and bio-sensor technology with electrochemical components to determine glucose levels. Designed to provide plasma-calibrated glucose values to patients in self-testing, the B. Braun Omnitest 5 BGMS requires a relatively small volume of whole blood $(0.5 \mu \mathrm{L})$ for analysis and requires approximately 5 seconds for measurement.

The purpose of this study was to assess the performance of the B. Braun Omnitest 5 BGMS for SMBG.

\section{MATERIALS AND METHODS}

\section{Subject}

The study was conducted from November 3-30, 2015 at the Hanil General Hospital, a 500-bed general hospital in Seoul, Korea. Subjects who had received a diagnosis of type 1 or type 2 diabetes were recruited from the Division of Endocrinology at Hanil General Hospital. A total of 120 subjects were enrolled in this study; however, data analysis was performed on capillary blood samples from 100 different subjects because 20 subjects were excluded based on the exclusion criteria of the study. Data were excluded from statistical analysis if (1) a handling error occurred, (2) no reference value was available, (3) a technical error occurred, (4) haematocrit value was outside the validated range of the respective BGMS, (5) the drift between the first and second reference measurement was $>4 \mathrm{mg} / \mathrm{dL}$ at blood glucose concentrations $\leq 100 \mathrm{mg} / \mathrm{dL}$, or $>4 \%$ at blood glucose concentrations $>100 \mathrm{mg} / \mathrm{dL}$, or (6) the maximum number of samples in a given blood glucose concentration category was already reached.

All subjects provided written informed consent, and the study protocol was conducted with institutional review board approval of Hanil General Hospital (KMC-2015ME-001).

\section{Methods}

\section{1) Precision}

Precision testing was conducted in accordance with Clinical and Laboratory Standards Institute (CLSI) EP05-A3 [7]. Glucose levels were measured in duplicate in each run, and two runs per day for 20 days were performed for three concentrations of control materials. B. Braun Omnitest 5 glucose control solution was supplied by the manufacturer. The calculated total coefficients of variation (CV) and SD were compared with the manufacturer's claims for precision.

\section{2) Linearity}

Linearity testing was conducted in accordance with CLSI EP06-A [8]. During linearity testing, specimens with the highest and lowest glucose concentrations were selected from the EDTA-containing whole blood specimens remaining after routine testing (elapsed time until completion of the test was less than 1 hour). The two specimens were mixed at ratios of 5:0, 4:1, 3:2, 2:3, 1:4, and $0: 5$, and these six concentrations were then measured in quadruplicate.

\section{3) Method comparison and system accuracy}

Finger-stick extraction of blood was performed on each subject using a lancing device and their blood glucose levels were tested using Meter 1 and Meter 2 to test the same drop of blood. Capillary blood samples were collected into two capillary tubes of blood for measurement of haematocrit levels and the YSI 2300 STAT PLUS (YSI 
Life Sciences, Yellow Springs, OH, USA) glucose reference measurement. Using one tube, haematocrit was analysed using the ADVIA 2120i Automated Hematology System (Siemens, Munich, Germany). Glucose measurement of the B. Braun Omnitest 5 BGMS was found to be within the valid haematocrit range of $20 \%-60 \%$. All data from haematocrit measurements fell within this claimed range. The other tube was then immediately centrifuged at 2,260 $\mathrm{g}$ for 5 minutes. Glucose levels were measured by glucose oxidase assay on the YSI 2300 STAT PLUS in duplicate. The ISO 15197 standard specifies that the blood glucose concentrations of blood samples should be distributed as follows: $5 \%<50 \mathrm{mg} / \mathrm{dL}, 15 \% \geq 50$ to $<80 \mathrm{mg} / \mathrm{dL}, 20 \% \geq$ 80 to $<120 \mathrm{mg} / \mathrm{dL}, 30 \% \geq 120$ to $<200 \mathrm{mg} / \mathrm{dL}, 15 \% \geq 200$ to $<300 \mathrm{mg} / \mathrm{dL}, 10 \% \geq 300$ to $<400 \mathrm{mg} / \mathrm{dL}$, and $5 \%>400$ $\mathrm{mg} / \mathrm{dL}$.

If sufficient numbers of native samples with blood glucose concentrations $<50 \mathrm{mg} / \mathrm{dL}$ were not available, adjusted capillary blood samples were prepared as follows: blood samples were collected in lithium heparin tubes, incubated at $25^{\circ} \mathrm{C}$ to allow for glycolysis, and gently mixed before testing. If sufficient numbers of native samples with blood glucose concentrations $>400 \mathrm{mg} / \mathrm{dL}$ were not available, additional samples were prepared as follows: blood samples were collected in lithium heparin tubes, supplemented with concentrated glucose solution $(40,000 \mathrm{mg} / \mathrm{dL}$ glucose in $0.9 \% \mathrm{NaCl})$, and gently mixed before testing [9]. In this study, the blood samples were distributed into different concentration categories based on the mean blood glucose reference values of the reference method (Table 1).

Native capillary samples were used at blood glucose concentrations of $>50 \mathrm{mg} / \mathrm{dL}$ to $\leq 400 \mathrm{mg} / \mathrm{dL}$ and adjusted capillary blood was used at blood glucose concentrations of $\leq 50 \mathrm{mg} / \mathrm{dL}$ and $>400 \mathrm{mg} / \mathrm{dL}$ in this study.

Tests using the B. Braun Omnitest 5 BGMS were performed by a well-trained technician to minimize user error and inter-user variance. BGMS tests were performed with three reagent system lots (F2QF03, F2QF04, and F2QF05). Two samples were excluded because of haemolysis and 18 samples were excluded because the concentration category was already filled. To minimize the time between the duplicate measurements, two measurements were performed for each reagent system lot.

Estimated differences with 95\% confidence intervals between the test and reference methods were derived from the linear regression method [10]. In addition, CEG analysis was performed and system accuracy was evaluated in conformance with the ISO 15197: 2013 standard.

The accuracy of the reference instrument was verified in accordance with the National Institute of Standards and Technology (Gaithersburg, MD, USA) reference material. Measurements taken by the reference method were performed at the clinical laboratory of Hanil General Hospital.

\section{Statistical Analysis}

System accuracy was assessed by comparing the BGMS measurement results with the respective mean result of the reference measurements. The data obtained from the B. Braun Omnitest 5 were plotted against the YSI 2300 STAT PLUS reference values and linear regression and CEG analyses were performed. Minimum system accuracy criteria were applied according to the ISO 15197: 2013 standard, by which the BGMS should meet the following criteria. (1) Criterion A: $95.0 \%$ of the measured glucose values should fall within either $\pm 15 \mathrm{mg} / \mathrm{dL}$ of the average comparison measurement result at glucose concentrations

Table 1. Capillary samples for the evaluation of system accuracy according to International Organization for Standardization 15197: 2013 standard

\begin{tabular}{ccll}
\hline $\begin{array}{c}\text { Concentration } \\
\text { category }\end{array}$ & $\begin{array}{c}\text { Percentage of } \\
\text { samples }(\%)\end{array}$ & $\begin{array}{c}\text { Glucose } \\
\text { concentration } \\
(\mathbf{m g} / \mathrm{dL})\end{array}$ & $\begin{array}{c}\text { Sample } \\
\text { type }\end{array}$ \\
\hline 1 & 5 & $\leq 50$ & Adjustment \\
2 & 15 & $>50-\leq 80$ & Native \\
3 & 20 & $>80-\leq 120$ & Native \\
4 & 30 & $>120-\leq 200$ & Native \\
5 & 15 & $>200-\leq 300$ & Native \\
6 & 10 & $>300-\leq 400$ & Native \\
7 & 5 & $>400$ & Adjustment \\
\hline
\end{tabular}


$<100 \mathrm{mg} / \mathrm{dL}$ or within $15 \%$ at glucose concentrations $\geq$ $100 \mathrm{mg} / \mathrm{dL}$. Each lot should pass acceptability criterion A. (2) Criterion B: 99.0\% of individual glucose measured values should fall within zones A and B of the CEG [11].

Microsoft Excel 2010 (Microsoft Co., Redmond, WA, USA) was used for data analysis.

\section{RESULTS}

\section{Precision}

The range for total CV was $1.5 \%-4.9 \%$ for the three lots of strips. In terms of both within-run precision and withinlaboratory precision, the manufacturer's claims were fulfilled (Table 2): SDs for each glucose concentration
$<100 \mathrm{mg} / \mathrm{dL}$ should be below $5 \mathrm{mg} / \mathrm{dL}$ and CV for each glucose concentration $\geq 100 \mathrm{mg} / \mathrm{dL}$ should be below $5 \%$.

\section{Linearity}

Over the concentration range of $52.5-548.0 \mathrm{mg} / \mathrm{dL}$, the coefficients of determination $\left(R^{2}\right)$ with the three reagent system lots were $0.9963,0.9986$, and 0.9962 (Fig. 1).

\section{Method Comparison and System Accuracy}

The glucose reference values ranged from 35 to 482 $\mathrm{mg} / \mathrm{dL}$. Two test strips from three individual strip lots (F2QF03, F2QF04, and F2QF05) were tested for each patient, for a total of 200 glucose meter results per lot. Statistics showing combined lot agreement of the B.

Table 2. Precision of B. Braun Omnitest 5 blood glucose monitoring system by using three levels of control material on three lots

\begin{tabular}{|c|c|c|c|c|c|c|c|}
\hline \multirow{3}{*}{ Strip lot } & \multicolumn{5}{|c|}{ Test result $(\mathrm{n}=\mathbf{8 0})$} & \multirow{2}{*}{\multicolumn{2}{|c|}{$\begin{array}{c}\text { Claim of manufacturer } \\
\text { Within-laboratory precision }\end{array}$}} \\
\hline & \multirow{2}{*}{$\begin{array}{c}\text { Control solution } \\
(\mathrm{mg} / \mathrm{dL})\end{array}$} & \multicolumn{2}{|c|}{ Within-run precision } & \multicolumn{2}{|c|}{ Within-laboratory precision } & & \\
\hline & & $\mathrm{SD}(\mathrm{mg} / \mathrm{dL})$ & $\mathrm{CV}(\%)$ & $\mathrm{SD}(\mathrm{mg} / \mathrm{dL})$ & CV (\%) & $\mathrm{SD}(\mathrm{mg} / \mathrm{dL})$ & CV (\%) \\
\hline \multirow[t]{3}{*}{ F2QF03 } & Level 1 (35-65) & 1.6 & 2.9 & 2.2 & 4.0 & $<5.0$ & \\
\hline & Level 2 (102-136) & 2.2 & 2.0 & 3.2 & 2.9 & & $<5.0$ \\
\hline & Level 3 (295-399) & 4.9 & 1.7 & 6.2 & 2.2 & & $<5.0$ \\
\hline \multirow[t]{3}{*}{ F2QF04 } & Level 1 (35-65) & 1.5 & 2.8 & 1.6 & 2.9 & $<5.0$ & \\
\hline & Level $2(102-136)$ & 2.8 & 2.7 & 3.4 & 3.2 & & $<5.0$ \\
\hline & Level 3 (295-399) & 5.1 & 1.8 & 6.8 & 2.4 & & $<5.0$ \\
\hline \multirow[t]{3}{*}{ F2QF05 } & Level 1 (35-65) & 1.9 & 3.5 & 2.3 & 4.1 & $<5.0$ & \\
\hline & Level $2(102-136)$ & 3.2 & 2.7 & 4.1 & 3.5 & & $<5.0$ \\
\hline & Level 3 (295-399) & 4.5 & 1.5 & 6.4 & 2.2 & & $<5.0$ \\
\hline
\end{tabular}
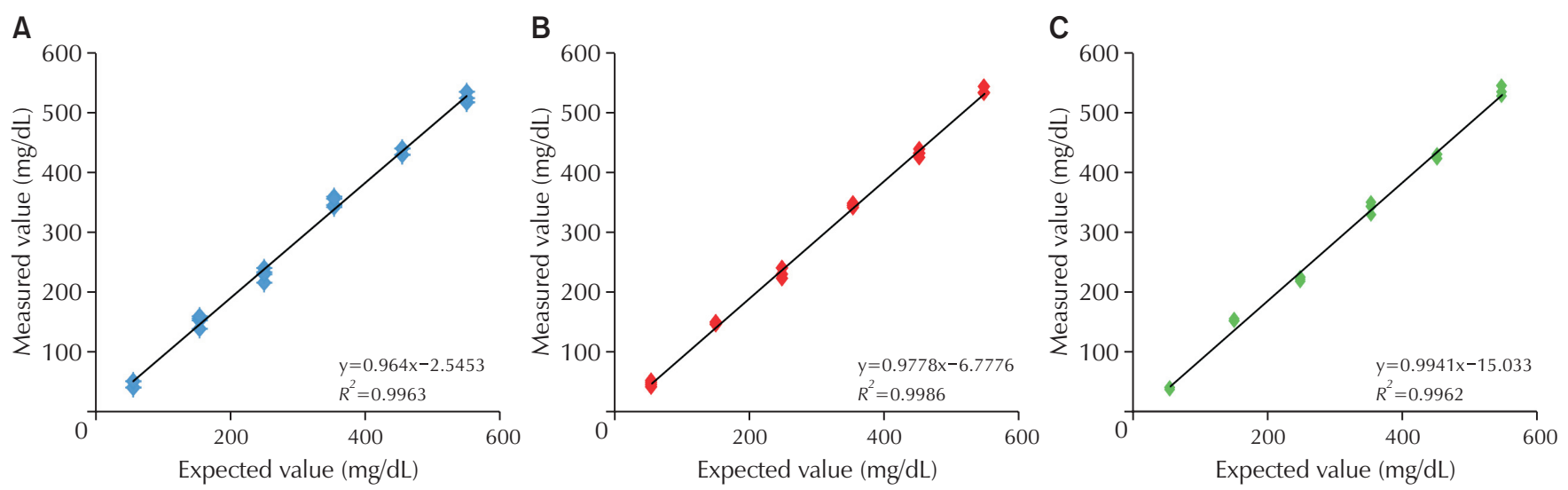

Fig. 1. Linearity of glucose concentrations measured by the three reagent system lots, B. Braun Omnitest 5. (A) F2QF03. (B) F2QF04. (C) F2QF05. 
Braun Omnitest 5 BGMS results are shown in Table 3 and Fig. 2. When applying the system accuracy criteria of ISO 15197: 2013, 100\% (54/54), 100\% (54/54), and $100 \%(54 / 54)$ of B. Braun Omnitest 5 BGMS values were within $\pm 15 \mathrm{mg} / \mathrm{dL}(<100 \mathrm{mg} / \mathrm{dL})$ for the three strip lots (F2QF03, F2QF04, and F2QF05), respectively. Additionally, 97.9\% (143/146), 95.9\% (140/146), and 99.3\% (145/146) were within $\pm 15 \%(\geq 100 \mathrm{mg} / \mathrm{dL})$ of the average reference value. For the overall concentrations, 98.5\% (197/200), 97.0\% (194/200), and 99.5\% (199/200) of specimens met these criteria (Table 4, Fig. 3). In CEG analyses, $100 \%$ of the values were within zones $\mathrm{A}$ and $\mathrm{B}$ of the consensus error grid for the system (Table 5, Fig. 4).

Table 3. Method comparison between B. Braun Omnitest 5 blood glucose monitoring system, and YSI 2300 STAT PLUS auto analyser (N=200)

\begin{tabular}{llcccc}
\hline Strip lot & Linear regression & 95\% CI slope & 95\% CI intercept & $R^{2}$ & No. \\
\hline F2QF03 & $y=0.9454 x+3.6801$ & $(0.931-0.960)$ & $(0.761-6.599)$ & 0.9887 & 200 \\
F2QF04 & $y=0.9299 x+4.5905$ & $(0.916-0.943)$ & $(1.807-7.374)$ & 0.9893 & 200 \\
F2QF05 & $y=0.9436 x+5.1553$ & $(0.931-0.956)$ & $(5.658-7.653)$ & 0.9916 & 200 \\
\hline
\end{tabular}

Abbreviation: CI, confidence interval.
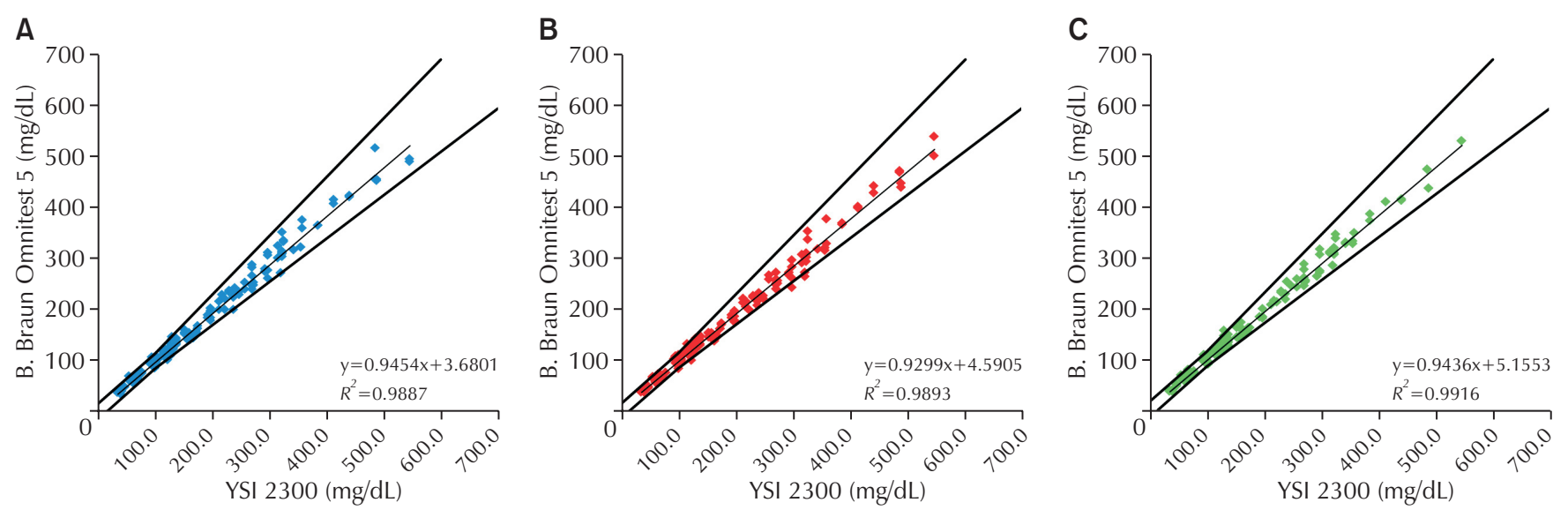

Fig. 2. Scatter plot of expected and measured glucose levels from method comparison test of Omnitest 5 blood glucose monitoring system (200 data points, duplicate measurements on a sample with each test strip lot, are shown). Solid lines indicate the limits stipulated in the International Organization for Standardization 15197: 2013. (A) F2QF03. (B) F2QF04. (C) F2QF05.

Table 4. System accuracy between B. Braun Omnitest 5 blood glucose monitoring system and YSI 2300 STAT PLUS auto analyser (N=200)

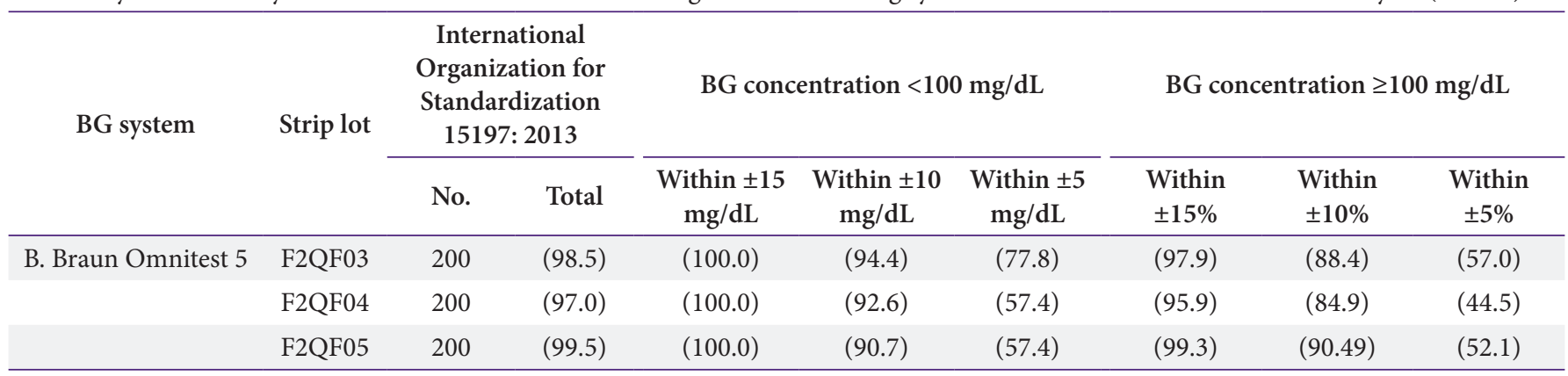

Values are presented as number or (\%).

Abbreviation: BG, blood glucose. 
A

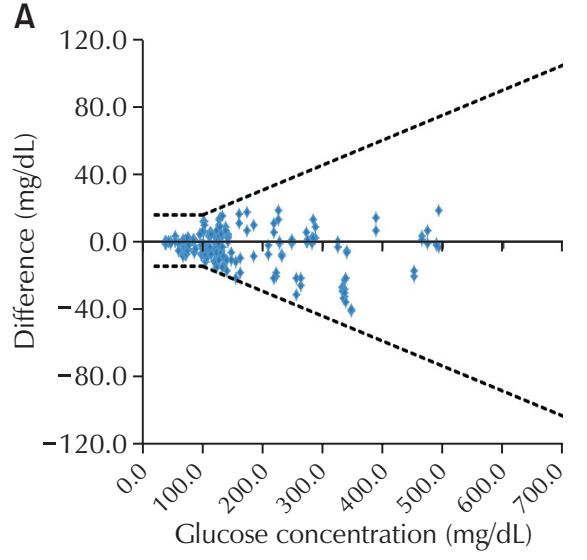

B

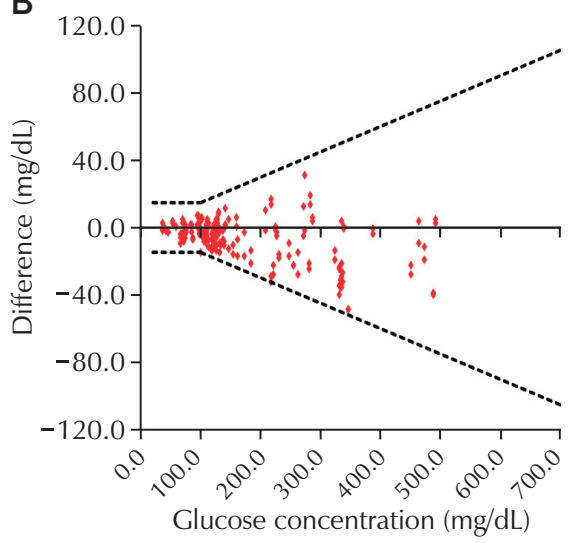

C

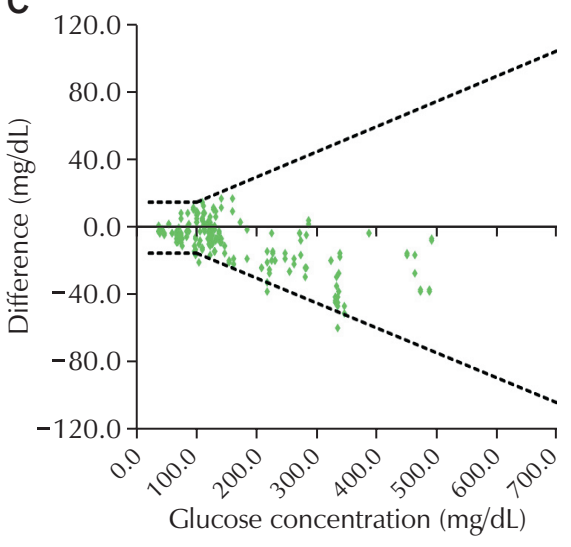

Fig. 3. Absolute difference plot between the blood glucose concentration results measured by the systems and respective comparison values measured with YSI 2300 STAT PLUS (200 data points, duplicate measurements on a sample with each test strip lot, are shown). Solid lines indicate the limits stipulated in the International Organization for Standardization 15197: 2013. (A) F2QF03. (B) F2QF04. (C) F2QF05.

Table 5. Consensus error grid analysis of glucose levels measured by B. Braun Omnitest 5 blood glucose monitoring system against YSI 2300 STAT PLUS auto analyser $(\mathrm{N}=200)$

\begin{tabular}{ccccccc}
\hline \multirow{2}{*}{ Blood glucose system } & \multirow{2}{*}{ Strip lot } & \multicolumn{5}{c}{ Consensus error grid zone } \\
\cline { 3 - 6 } & & Zone A & Zone B & Zone C & Zone D & Zone E \\
\hline B. Braun Omnitest 5 & F2QF03 & $199 / 200(99.5)$ & $1 / 200(0.5)$ & $0 / 200(0)$ & $0 / 200(0)$ & $0 / 200(0)$ \\
& F2QF04 & $198 / 200(99.0)$ & $2 / 200(1.0)$ & $0 / 200(0)$ & $0 / 200(0)$ & $0 / 200(0)$ \\
& F2QF05 & $200 / 200(100.0)$ & $0 / 200(0)$ & $0 / 200(0)$ & $0 / 200(0)$ & $0 / 200(0)$ \\
\hline
\end{tabular}

Values are presented as number (\%).

A

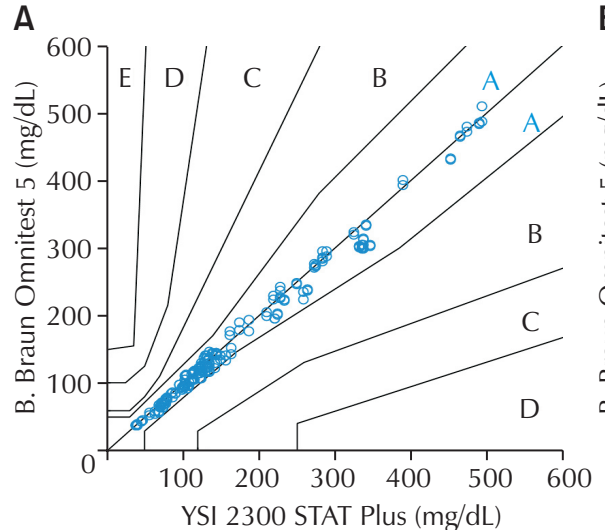

B

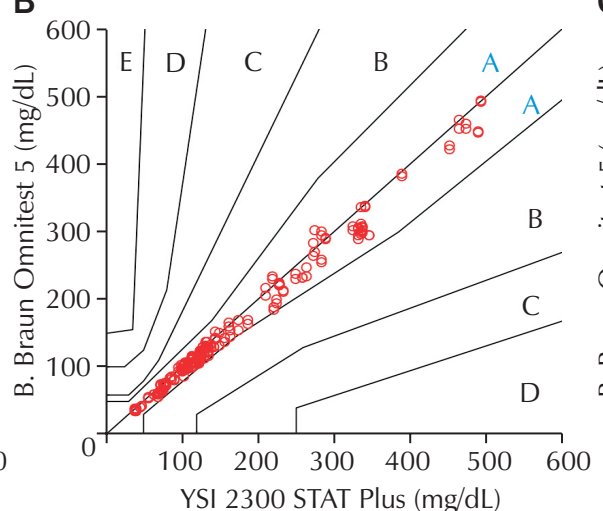

C

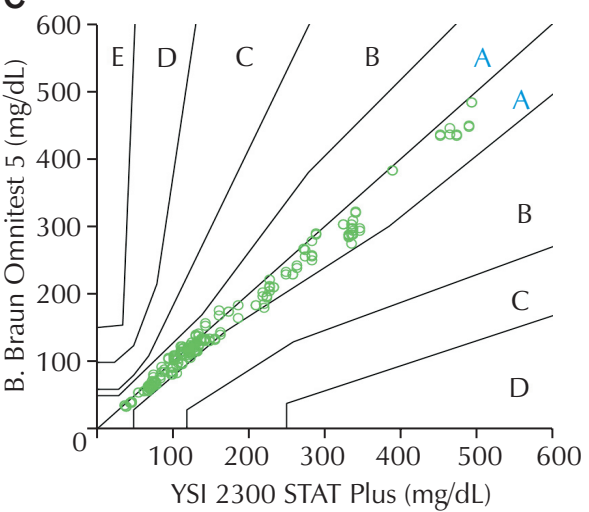

Fig. 4. Consensus error grid analysis of capillary blood glucose results. Each specimen was measured in duplicate by each method. Zone A, clinically accurate (no effect on clinical action); zone B, clinically acceptable (altered clinical action-little or no effect on clinical outcome); zone C, altered clinical action-likely to affect clinical outcome; zone $\mathrm{D}$, altered clinical action-may have significant medical risk; and zone E, altered clinical action-may have dangerous consequences. (A) F2QFO3. (B) F2QF04. (C) F2QF05. 


\section{DISCUSSION}

Accurate performance of glucose meters is the most critical factor of glycaemic control for a diabetic patient. Hence, the criteria for the performance evaluation of glucose meters have become more stringent as required by regulatory agencies [12]. Most glucose meters are calibrated using capillary blood, after which reference equipment is employed to calibrate the plasma. Therefore, the glucose meter and reference equipment should utilise capillary blood for accurate performance evaluation. The blood glucose concentration levels and quantities manipulated in the evaluation should be in compliance with ISO 15197. Occasionally, it is difficult for the subject (participant who donates the blood) to measure the capillary blood with the reference equipment. Thus, in common domestic evaluations, the blood glucose meter is evaluated using capillary blood, whereas the reference equipment is assessed using venous blood [13,14]. Nevertheless, this study evaluated ISO 15197: 2013 by employing capillary blood for both the evaluation criteria and the exclusion criteria applied in data analysis.

Upon measurement of the capillary blood collected from participants, the blood sample was tested again using the reference equipment. For glucose concentrations below $100 \mathrm{mg} / \mathrm{dL}$, the difference between two measurements determined using the reference equipment should be less than $4 \mathrm{mg} / \mathrm{dL}$ and should be within the range of max bias $\pm 4 \%$ for glucose concentrations above $100 \mathrm{mg} /$ dL. Otherwise, the subject should be excluded from the analysis. This is to minimize variance in the reference equipment. ISO 15197 states that samples with glucose concentrations under $50 \mathrm{mg} / \mathrm{dL}$ and over $400 \mathrm{mg} / \mathrm{dL}$ can be replaced with manipulated blood during evaluation. However, this is done for extreme cases of patients with severe hypoglycaemia. Blood samples can be manipulated by decreasing sugar levels by approximately $7 \mathrm{mg} / \mathrm{dL}$ each hour, and samples of $50 \mathrm{mg} / \mathrm{dL}$ glucose concentration can be produced through glycolysis after collecting capillary blood. When glucose concentration exceeds $400 \mathrm{mg} / \mathrm{dL}$, a $40,000 \mathrm{mg} / \mathrm{dL}$ stock solution is prepared for addition into the blood. After setting the target for blood glucose concentration, the blood glucose concentration in the collected sample is measured. The formula applied multiplies the difference in blood glucose concentrations (current volume subtracted from target volume) and divides the product by the stock concentration. With the exception of the sample described above, all blood samples were evaluated utilizing non-manipulated blood.

In blood glucose measurement, Parkes proposed consensus error grid analysis techniques in the 2000s to improve the error grid analysis techniques first introduced by Clarke in the mid-1980s [11]. Consensus error grid analysis is a method that plots measured values in 5 error regions (zone A, B, C, D, and E). Based on the consensus of survey participants, glucose results in zones $\mathrm{A}$ and B lead to little or no effect on clinical outcome, whereas results in zones $\mathrm{C}$ to $\mathrm{E}$ lead to an increased risk of an adverse outcome. Evaluation of a BGMS requires the use of the prevailing method of error grid analysis, as regression analysis and the absolute value of the difference or percentage techniques analyse the measurement error from different concentrations with the same standard and do not reflect the importance of measurement values according to blood glucose concentration.

Hence, the ISO/DIS 15197: 2013, consensus error grid analysis is required and 99\% of measurement values must be within zone A or B. Consensus error grid analysis demonstrated no risk of adverse effects of medical decisions in treatment, as outlier values of the B. Braun Omnitest 5 measurements were within zone B. A similar pattern of difference was observed in comparisons between the B. Braun Omnitest 5 BGMS and YSI 2300 Stat Plus. All 600 tests fell in zone A or B of the consensus error grid. Thus, differences in results would not affect clinical actions (for zone A) or have little or no effect on clinical outcomes, even with altered clinical action (for zone B).

In addition to the accuracy test, comprehensive assessment of precision and linearity showed that the diagnostic equipment and other factors displayed outstanding performance.

In conclusion, the B. Braun Omnitest 5 provided reliable results and satisfied the ISO 15197: 2013 accuracy criteria, demonstrating good performance in terms of 
precision and linearity. Therefore, the B. Braun Omnitest 5 is expected to be useful in self-testing by a BGMS.

\section{ACKNOWLEDGEMENTS}

The authors would like to thank In Suk Kim and Sang Won Kim for their help with this study.

This study was supported by Infopia Co. Ltd., Anyang, Korea.

\section{REFERENCES}

1. International Diabetes Federation. IDF diabetes atlas. 7th ed. Brussels: International Diabetes Federation, 2015.

2. American Diabetes Association. Standards of medical care in diabetes 2015: glycemic targets. Diabetes Care 2015;38(Suppl 1):S33-S40.

3. The Diabetes Control and Complications Trial Research Group. The effect of intensive treatment of diabetes on the development and progression of long-term complications in insulin-dependent diabetes mellitus. N Engl J Med 1993;329:977-86.

4. UK Prospective Diabetes Study (UKPDS) Group. Intensive blood-glucose control with sulphonylureas or insulin compared with conventional treatment and risk of complications in patients with type 2 diabetes (UKPDS 33). Lancet 1998;352:837-53.

5. Virdi NS, Mahoney JJ. Importance of blood glucose meter and carbohydrate estimation accuracy. J Diabetes Sci Technol 2012;6:921-6.

6. International Organization for Standardization. In vitro diagnostic test systems: requirements for blood glucose monitoring systems for self-testing in managing diabetes mellitus. Geneva: International Organization for Standardization, 2013.

7. Clinical and Laboratory Standards Institute. Evaluation of precision of quantitative measurement procedures: approved guideline. 3rd ed. Wayne (PA): Clinical and Laboratory Standards Institute, 2014.

8. Clinical and Laboratory Standards Institute. Evaluation of linearity of quantitative measurement procedures: a statistical approach: approved guideline. Wayne (PA): Clinical and Laboratory Standards Institute, 2003.

9. Khan MI, Weinstock RS. Carbohydrates. In: Henry JB, editor. Clinical diagnosis and management by laboratory methods. 22nd ed. Philadelphia (PA): WB Saunders, 2011:210-25.

10. Clinical and Laboratory Standards Institute. Method comparison and bias estimation using patient samples: approved guideline. 2nd ed. Wayne (PA): Clinical and Laboratory Standards Institute, 2010.

11. Parkes JL, Slatin SL, Pardo S, Ginsberg BH. A new consensus error grid to evaluate the clinical significance of inaccuracies in the measurement of blood glucose. Diabetes Care 2000;23:1143-8.

12. Thorpe GH. Assessing the quality of publications evaluating the accuracy of blood glucose monitoring systems. Diabetes Technol Ther 2013;15:253-9.

13. Lee JH, Cha YJ. Performance evaluation of BAROZEN $\mathrm{H}$, a networking blood glucose monitoring system for medical institutions. Lab Med Online 2015;5:69-76.

14. Kim YB, Seo JY, Lee SY, Park HD. Performance evaluation of glucometer Barozen H based on ISO 15197 standards. Lab Med Online 2015;5:6-14. 


\section{자가혈당측정기 B. Braun Omnitest 5 성능평가} 전경소 ${ }^{\bullet} \cdot$ 신미선 $^{2}$

한전의료재단 한일병원 ${ }^{1}$ 진단검사의학과, ${ }^{2}$ 내분비내과

배경: 최근 자가혈당측정기로 개발이 완료된 B. Braun Omnitest 5 (Infopia Co. Ltd., Korea)의 성 능평가를 진행하였다.

방법: 정밀도평가는 정도관리물질 3농도를 이용하여 Clinical and Laboratory Standards Institute EP5-A3에 따라 평가하였다. 직선성은 환자의 혈액을 이용하여 $52.5-548.0 \mathrm{mg} / \mathrm{dL}$ 의 농도까지 평 가하였으며, 정확도 평가는 100 명의 참여자의 손끝 모세혈을 이용하여 평가하였다. International Organization for Standardization (ISO) 15197: 2013 정확성 평가기준에 따라 평가하였으며, 기 준장비로는 YSI 2300 STAT PLUS 혈당측정기(YSI Life Sciences, USA)를 이용하였다.

결과: 총 3개의 lot에서 평가된 모든 항목의 변이개수는 1.5\%-4.9\%를 나타내었으며 이는 검사 내 정밀도, 검사실 내 정밀도 모두 제조사의 요구를 만족하였다. ISO 1597: 2013에서는 측정된 혈당 값과의 허용 차이가 $100 \mathrm{mg} / \mathrm{dL}$ 미만의 검체에서는 $95.0 \%$ 의 결과가 오차범위 $\pm 15 \mathrm{mg} / \mathrm{dL}$ 안에, $100 \mathrm{mg} / \mathrm{dL}$ 이상의 검체에서는 $95.0 \%$ 의 결과가 $\pm 15 \%$ 이내에 들것을 권고하고 있는데, B. Braun Omnitest 5의 평가결과 ISO 15197: 2013의 기준을 만족하였으며 각 lot별로 98.5\% (197/200), 97.0\% (194/200), 그리고 99.5\% (199/200)의 결과를 보여주었다. Consensus error grid 분석에 서는 각각 $99.5 \%, 99.0 \%, 100.0 \%$ 의 측정값이 zone A에 만족하였으며, 3 lot 평균 $99.0 \%$ 가 A영 역 내에 포함되었다.

결론: B. Braun Omnitest 5는 신뢰할 만한 평가결과를 나타냈으며 ISO 15197: 2013 정확성 기준을 만족하였고, 재현성 및 직선성에서도 만족할 만한 성능을 보여주었다. 따라서 B. Braun Omnitest 5는 자가혈당측정기로서 적절한 혈당측정시스템으로 평가된다.

(J Lab Med Qual Assur 2016;38:234-242)

교신저자: 전경소

우)01450 서울시 도봉구 우이천로 308 , 한전의료재단 한일병원 진단검사의학과

Tel: 02)901-3720, Fax: 02)901-3606, E-mail: jks3393@hanmail.net 